\title{
Richness and abundance of granivorous vertebrates determine acorn removal patterns in a human modified oak forest
}

\author{
Felipe Barragán (1), \\ Ernesto I Badano ${ }^{(2)}$, \\ David Douterlungne ${ }^{(1)}$, \\ Joel Flores ${ }^{(2)}$
}

\begin{abstract}
Most forests of the Earth have been affected by human activities and this can alter the plant-animal interactions on which depend the functional integrity of these ecosystems. In this study, we assessed the relationships between acorn removal rates and the richness and abundance of granivorous vertebrates along a forest-edge-clearing gradient. We also evaluated whether removal rates differed among oak species with different acorn size. To this purpose, a field experiment was performed including acorns of five oak species, which were exposed to seed consumers in the three different habitats (forest interior, man-made clearings and the edge between these habitats). The experimental units consisted in five paper trays containing 50 acorns of each oak species located at different distances from the edge towards the forest and the man-made clearing $(0,20$ and $50 \mathrm{~m})$. Experimental sites were equipped with phototraps to record the identity of the visiting granivorous vertebrates. Richness and abundance of granivores increased from the edge towards the forest interior, while the converse patterns were observed in the man-made clearing. For most oak species, acorn removal patterns was positively correlated with richness and abundances of granivores, though in all habitats smallsized acorns were removed much faster and in larger proportions than bigsized acorns. Although these results are specific for the study site, they suggest that man-made clearings reduce the richness and abundance of granivores, thus negatively affecting the secondary dispersion of zoochoric tree species towards open habitats. Further, it also seems that large-seeded oak species face greater dispersal limitations than small-seeded oaks, because of the lack of animals able to scatter them from the forest to the clearings.
\end{abstract}

Keywords: Acorn Size, Forest Gaps, Land Use Change, Man-made Clearing, Species Diversity.

\section{Introduction}

Large well-preserved forests are currently rare, as most forest ecosystems persist as part of human-modified landscapes (Paul \& Crutzen 2006). In the past century, human activities reduced the world's forests cover by almost $50 \%$ and this decline is expected to rise due to the expansion of the agricultural frontier (FAO 2010). These activities, however, strongly interfere with key ecological processes that take place in the forests, including seed dispersal, tree recruit- ment, seed predation and herbivory, among several other ecosystem functions that depend on local biodiversity (De Blois et al. 2002).

In forests dominated by zoochoric trees, the recruitment of these species in gaps generated by natural disturbances (e.g., sumers that unintentionally disperse plant propagules from the forest interior towards open sites (Schleimann \& Bockheim 2011). Small vertebrates, such as mice and tree fall) mainly depends on seed con-

(1) CONACYT-IPICYT, División de Ciencias Ambientales, Instituto Potosino de Investigación Científica y Tecnológica, Camino a la Presa San José 2055, Lomas 4 a Sección, C.P. 78216, San Luis Potosí, SLP (México); (2) IPICYT-División de Ciencias Ambientales, Instituto Potosino de Investigación Científica y Tecnológica, Camino a la Presa San José 2055, Lomas $4^{\text {a }}$ Sección, C.P. 78216, San Luis Potosí, SLP (México)

@ Felipe Barragán (felipe.barragan@ipicyt.edu.mx)

Received: Sep 05, 2016 - Accepted: Jan 21, 2018

Citation: Barragán F, Badano El, Douterlungne D, Flores J (2018). Richness and abundance of granivorous vertebrates determine acorn removal patterns in a human modified oak forest. iForest 11: 329-337. - doi: 10.3832/ifor2216-011 [online 2018-04-18]

Communicated by: Gianfranco Minotta birds, are important seed dispersers in forest ecosystems, but the opening of clearings for agriculture and cattle grazing alters their activity and distribution patterns (Caro \& Sherman 2012, Ramos-Palacios \& Badano 2014). The opening of man-made clearings also affects large and medium sized seed consumers. These animals, rather than disperse seeds, contribute to maintain the flows of matter and energy in forests, but deforestation and habitat fragmentation are dramatically reducing their diversity and abundance in these ecosystems (Redford 1992, Canale et al. 2012). Indeed, most granivores usually avoid visiting man-made clearings because these habitats lack of "biological legacies" (e.g., remaining trunks and branches) that provide them refuge from predators (Rizkalla \& Swihart 2007, Swihart et al. 2003, Schleimann \& Bockheim 2011, Canale et al. 2012).

Another important feature of human modified forests (hereafter, HMF) are the edge effects, which embrace all processes occurring in the boundaries between forests and man-disturbed sites (Cadenasso \& Pickett 2000). Edge effects can alter the richness and abundance of granivorous vertebrates, which usually decrease from the forest interior towards the edge, while 
only a few species visit large man-made clearings (Kattan \& Alvarez-López 1996, Cordeiro \& Howe 2001, Wright 2003, Ramos-Palacios et al. 2014). Therefore, most seed consumers can be expected to be concentrated within the forest remnants, while a few of them would visit man-made clearings. Further, several studies have assessed how increasing distance to edges affects seed removal by vertebrates, but their results are not fully consistent. Some authors have reported increased seed removal rates inwards the forest (Sork 1983, Bustamante et al. 2012, Ramos-Palacios \& Badano 2014), while others found higher removal rates at forest edges (Donoso et al. 2003, Kollmann \& Buschor 2003, LópezBarrera et al. 2005) or even in man-made clearings (Díaz et al. 1999). These discrepancies have been attributed to the chemical composition of seeds, as highly palatable seeds are quickly removed irrespectively of the habitat they are located, or differences in seed size, as bigger seeds are only removed by large granivores visiting the different habitats in the HMF (Donoso et al. 2003, Bustamante et al. 2012, ReyBenayas et al. 2015). Nevertheless, it remains largely unexplored whether changes in the richness and abundance of granivores are correlated with seed removal patterns along forest-edge-clearing gradients. Indeed, these relationships are likely to vary across different tree species, as they can differ in seed size and seed palatability (Smallwood et al. 2001, Steele et al. 2001). Given the elevated rates of land-use change to which forests are currently subjected, evaluating these relationships is critical to understand how human activities affect the processes linked to seed dispersal in these ecosystems, which in turn could help to design better conservation and management strategies addressed to preserve the functional integrity of HMF.

In this study, we assessed these relationships in a HMF dominated by oaks (Quercus spp., Fagaceae). We focused on this forest type because these tree species are widely distributed across temperate biomes of the Northern Hemisphere and their acorns are consumed by several granivorous vertebrates (Bossema 1979, Nixon 1993). Several authors proposed that the structural integrity and biodiversity of these forests largely depend on the trophic interactions between acorns and their consumers (Wolff 1996, Kirkpatrick \& Pekins 2002, Steele \& Smallwood 2002, López-Barrera \& Manson 2006, Vander Wall 2010, Ramos-Palacios et al. 2014). Temperate forests of Mexico, in particular, are composed by several oak species that produce acorns largely different in size and chemical composition, while they also harbor an elevated diversity of vertebrates that consume them (Nixon 1993, Zavala-Chávez 2001). However, these oak forests have been intensely affected by man-made clearings during the past two centuries (Rosete-Vergés et al. 2014) and this may have altered these plant-animal interactions.

We performed a field experiment to answer the following questions: (1) how do acorn removal rates vary across oak species along the forest-edge-clearing gradient? (2) do richness and abundance of granivores differ across habitats of these HMF? and (3) are acorn removal rates related with the richness and abundance of granivores along the forest-edge-clearing gradient? Our working hypothesis states that richness and abundance of granivorous vertebrates should decrease from the interior of forests toward man-made clearings, thus acorn removal rates should also decrease in that direction.

\section{Materials and methods}

\section{Study area}

This study was conducted in the Wildlife Management Unit "La Laguna" (21 $58^{\circ} \mathrm{N}$, $100^{\circ} 34^{\prime} \mathrm{W}$, elevation $2100 \mathrm{~m}$ a.s.l.), located in westernmost section of Sierra Madre Oriental, State of San Luis Potosí, Mexico. Climate in this region is temperate (mean annual temperature $18{ }^{\circ} \mathrm{C}$ ) and $90 \%$ of rainfalls (mean annual precipitation 500-650 $\mathrm{mm}$ ) are concentrated between June and November (García 2004). Vegetation is composed by continuous oak forests, but local people opened clearings of varying size (5-25 ha) that currently cover $30 \%$ of the study area. These clearings are used to develop different activities (e.g., subsistence farming, cattle grazing and mixed management practices) and this has generated an extremely complex HMF.

The study was carried out in a single large clearing (14 ha) sporadically used for cattle grazing. This clearing has sharp edges with forests composed by red and white oaks. Red oaks include Quercus affinis Scheidw. (1837), Quercus castanea Née (1801), Quercus jonesii Trel. (1924), Quercus crassifolia Humb. \& Bonpl. (1809), Quercus eduardii Trel. (1924), Quercus mexicana Bonpl. (1809) and Quercus viminea Trel. (1924). White oaks include Quercus laeta Liebm. (1954), Quercus resinosa Liebm. (1954) and Quercus rugosa Née (1801). All these species bloom between April and June and release their fruits between August and November (Martínez 1981).

\section{Oak species and acorn collection}

Most oak species at the study site have mast-seeding years interposed with several years of low seed production (Zavala-Chávez 2001), thus we focused on those species that had mast acorn production in 2015. This included three red oaks (Q. affinis, Q. castanea and Q. eduardii), and two white oaks (Q. resinosa and Q. rugosa). These oak species strongly differ in acorn sizes and they can be serialized in the following decreasing order: Q. resinosa $(3.0-6.0 \mathrm{~cm}$ length $\times 1.5-3.0 \mathrm{~cm}$ width), $Q$. rugosa (2.0$2.5 \mathrm{~cm}$ length $\times 1.5-2.5 \mathrm{~cm}$ width), Q. castanea $(1.0-2.0 \mathrm{~cm}$ length $\times 1.0-1.5 \mathrm{~cm}$ width),
Q. affinis $(0.5-1.3 \mathrm{~cm}$ length $\times 0.8-1.0 \mathrm{~cm}$ width), and Q. eduardii (0.8-1.0 cm length $\times$ 0.4-0.6 cm width - Martínez 1981).

Between September and October 2015, after the occurrence of primary dispersion, we collected mature acorns beneath the canopy of ten parental trees of each species in the study area. However, because acorns collected in the field are often parasitized by insect or fungi (González-Salvatierra et al. 2013, Ramos-Palacios et al. 2014), we took off the cupules of acorns and placed the nuts in 20-liter containers filled with water. After $2 \mathrm{~h}$ in water, sunken acorns were assumed to be viable (Gribko \& Jones 1995) and then used in the experiment, while floating acorns were discarded.

Experimental design and data collection

To assess whether richness and abundance of acorn consumers differed across the forest-edge-clearing gradient, as well as to assess how this influences acorn removal rates, we located four sampling stations at the forest edge, spaced $50 \mathrm{~m}$ from each other. From each of these stations, we laid out a 100-m line transect perpendicular to the forest edge, taking care of maintaining equivalent distances in all cardinal directions between these sites and forest edges to avoid interference (Fig. 1a). We established sampling stations along each transect at $0 \mathrm{~m}, 20 \mathrm{~m}$ and $50 \mathrm{~m}$ from the edge. Hereafter we will refer to the forest edge as distance 0 , while distances inwards the forest and the clearing will be respectively referred as positive $(20 \mathrm{~m}$ and $50 \mathrm{~m})$ and negative values ( $-20 \mathrm{~m}$ and $-50 \mathrm{~m})$.

At each experimental site, we fixed five circular paper trays $(20-\mathrm{cm}$ diameter, $1-\mathrm{cm}$ deep) to the soil with $8-\mathrm{cm}$ iron nails (Fig. 1a). Each tray was randomly assigned to contain 50 acorns of an oak species (Q. affinis, Q. castanea, Q. eduardii, Q. rugosa and Q. resinosa). The acorn removal experiment started at 18:00 h on November $3^{\text {rd }} 2015$ and, to estimate acorn removal rates, we counted the number of remaining acorns in each tray every $12 \mathrm{~h}$ (06:00 and 18:00). The experiment was finished on November $7^{\text {th }}$ at 06:00 h (after $84 \mathrm{~h}$ ), when more than $70 \%$ of acorns were removed from trays. To register the identity of animals that visited the trays, we mounted two digital phototraps on each experimental unit (Digital Scouting Camera Model $1231^{\oplus}$, Cuddeback, De Pere, WI, USA). These phototraps were fixed $1 \mathrm{~m}$ above the soil on wood sticks located $75 \mathrm{~cm}$ away from acorn trays. Wood sticks had an inclination of $45^{\circ}$ to focus the lens of cameras directly on the trays (Fig. 1a). Cameras were adjusted to the highest resolution (20 megapixels) and movement sensors were adjusted to maximum sensitivity to record both large and small vertebrates.

\section{Statistical analyses}

We used failure-time-analyses to compare acorn removal rates among oak species 
and distances from the forest edge. In these analyses, all acorns had a value of 1 at the beginning of the experiment, while the removal of an acorn from a given tray at a given monitoring time was considered a "failure" and its value was changed to zero. Acorn removal rates were estimated with the Kaplan-Meier's method (Kaplan \& Meier 1958) and the Gehan's generalized Wilcoxon test was used to compare these values among treatments (Kleinbaum \& Klein 2012). When differences were found, pairwise Gehan's Wilcoxon tests were used to assess differences between treatments (=sites). These analyses were firstly used to assess overall species and distance-to-forest effects in acorn removal rates. After that, we compared acorn removal rates among oak species at each distance from the forest edge, as well as those of each oak species across the forest-edge-clearing gradient. All the statistical analyses were conducted in $\mathrm{R}$ ver. 3.0 ( $\mathrm{R}$ Development Core Team 2016).

Data obtained with phototraps were used to determine the habitat preferences of the different acorn consumers. To this purpose, we pooled the total visitation frequencies of each animal species (i.e., number of times each species was shot by phototraps) across sampling stations located at each distance from the forest edge. Photographs where animals did not consume acorns were discarded from these analyses. These data were used to perform Monte Carlo randomization tests to determine whether visitation frequencies of each animal species at each distance from the forest edge were higher or lower than expected by chance. For this, we generated randomly expected distribution frequencies of each animal species by resampling 1000 times their observed visitation frequencies across all distances from the forest edge and the probability ( $p$-value) for coincidence between observed and expected frequencies was computed (Slade 1999). The null hypothesis is that, if the spatial distribution of species is due to stochastic processes, then they must display random distribution patterns across distances from the forest edge. When $\mathrm{p}<0.05$, the hypothesis is rejected and the spatial distribution of species is considered to be regulated by deterministic processes (Fortin \& Jacquez 2000). Therefore, a visitation frequency either higher or lower than expected by chance indicates the animal species is positively or negatively associated to that habitat, respectively. These analyses were conducted with the Monte Carlo module of PopTools 3.2 (Hood 2011).

Simple linear regressions were used to determine whether richness and abundance of acorn consumers were related with the distance to the forest edge, as well as to assess whether acorn removal patterns were related with these two variables. Richness of acorn consumers (i.e., number of species recorded with phototraps at each sampling site during the ex- periment) and the total abundance of granivores at each site (i.e., total number of granivores recorded at each sampling station across the entire experiment), were regressed against the distance to the for-

est edge. Also, we tested the correlation of richness and abundance of granivores with the total number of removed acorns at each site as well as with the number of removed acorns of each oak species. Finally,
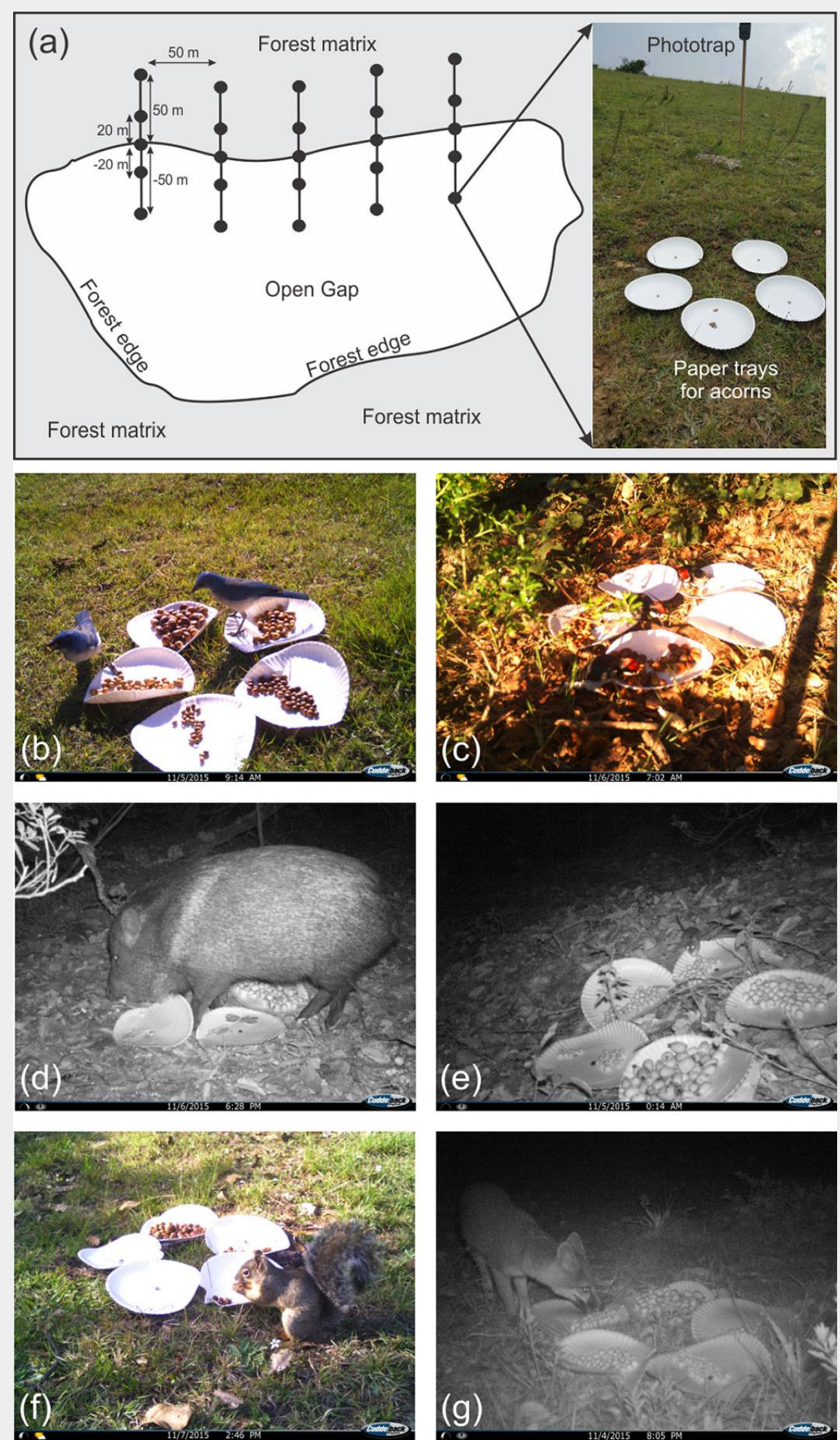

Fig. 1 - Schematic view of the experimental design (a) including two distances inwards the forest $(20 \mathrm{~m}$ and $50 \mathrm{~m})$, the forest edge $(0 \mathrm{~m})$, and two distances towards the open gap $(-20 \mathrm{~m}$ and $-50 \mathrm{~m})$. The figure also shows the paper trays on which acorns were placed at experimental sites and the phototraps used to record the granivores. Consumers captured by phototraps during daytime (color pictures) and night (blackwhite pictures) were: Aphelocoma ultramarina (b), Melanerpes formicivorus (c), Pecari tajacu (d), Peromyscus sp. (e), Sciurus oculatus (f) Urocyon cinereoargenteus (g). 

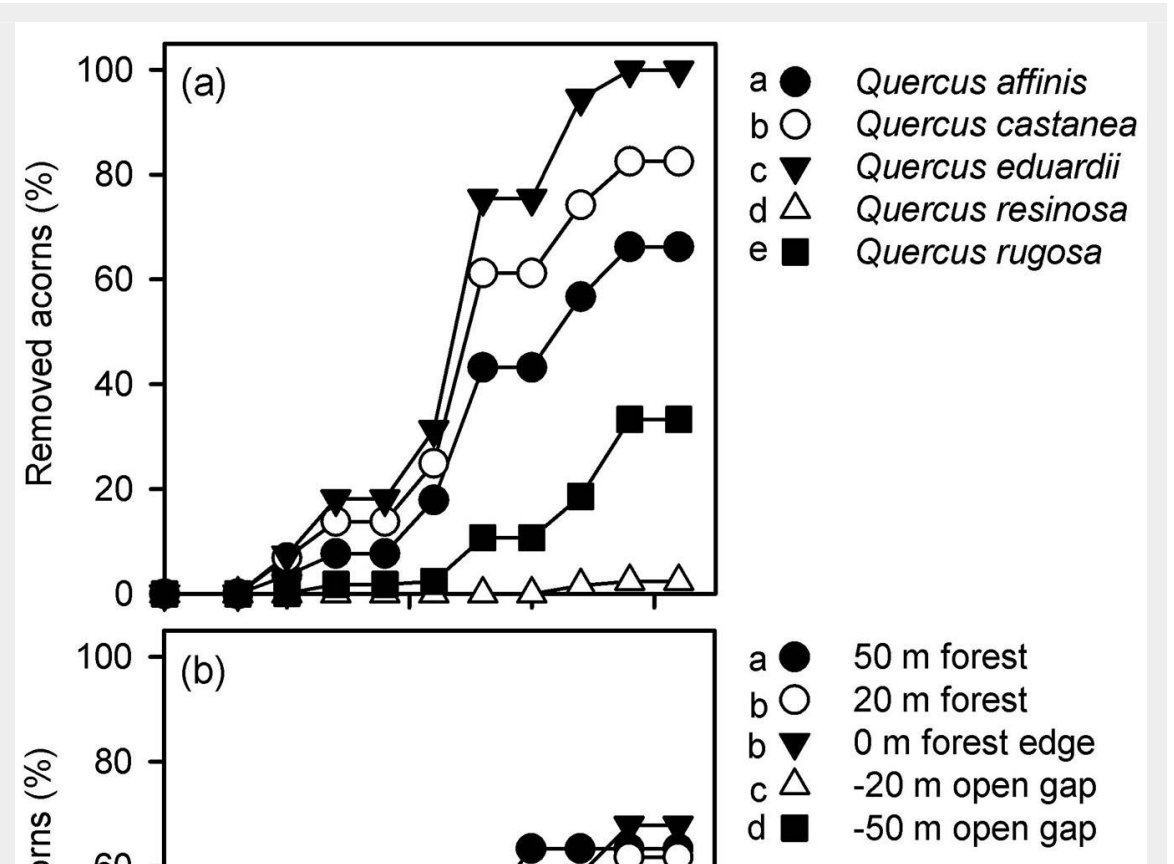

Fig. 2 - Acorn removal rates estimated for each oak species irrespective of the habitat in which they were located (a) and acorn removal rates estimated at each distance from the forest edge irrespective of the oak species (b). Different letters on the side of symbols indicate significant differences $(p<0.05)$ between mean removal rates after Gehan's Wilcoxon test.

to assess whether some granivores had ent oak species because this would require stronger effects than others on acorn re- knowing the acorn preferences of each moval, we regressed the total number of consumer, but our experimental design did removed acorns against the individual not allow to gather these data. All regresabundance of each granivore species. No sion analyses described above were conanalyses were conducted to assess the ef- ducted in R 3.0 (R Development Core Team fects of each acorn consumer on the differ- 2016).

Tab. 1 - Results of failure-time analyses to compare acorn removal rates among oak species at each distance from the forest edge (a), as well as among distances from the forest edge for each oak species (b). Gehan's Wilcoxon statistic (GWS), the degrees of freedom (df) and the associated $p$-value of each analysis are reported.

\begin{tabular}{lcccc}
\hline Comparison & Class & GWS & df & Prob. \\
\hline (a) Oak species at & $50 \mathrm{~m}$ (forest) & 577.625 & 4 & $<0.001$ \\
each distance from & $20 \mathrm{~m}$ (forest) & 530.907 & 4 & $<0.001$ \\
the forest edge & $0 \mathrm{~m}$ (edge) & 595.081 & 4 & $<0.001$ \\
& $-20 \mathrm{~m}$ (clearing) & 559.534 & 4 & $<0.001$ \\
& $-50 \mathrm{~m}$ (clearing) & 513.109 & 4 & $<0.001$ \\
(b) Distances from the & Q. affinis & 257.628 & 4 & $<0.001$ \\
forest edge for each & Q. castanea & 175.13 & 4 & $<0.001$ \\
species & Q. eduardii & 273.22 & 4 & $<0.001$ \\
& Q. resinosa & 5.548 & 4 & 0.235 \\
& Q. rugosa & 530.907 & 4 & $<0.001$ \\
\hline
\end{tabular}

\section{Results}

\section{Acorn removal patterns}

Acorn removal rates estimated irrespectively of the distance to the forest edge significantly differed among oak species (Gehan's Wilcoxon statistic $=2462.635, \mathrm{df}=4$, $p<0.001$ ). Pairwise comparisons indicated that removal rates were always higher for red oaks (Q. affinis, Q. castanea and Q. eduardii) than for white oaks (Q. resinosa and Q. rugosa - Fig. 2a). The highest removal rate was recorded for the oak species with smaller acorns ( $Q$. eduardii), whose acorn trays were completely depleted after $72 \mathrm{~h}$ (Fig. 2a). In contrast, the oak species with bigger acorns ( $Q$. resinosa) had the lowest removal rate, with more than $90 \%$ of its acorns remaining on the trays by the end of the experiment (Fig. 2a). Removal rates estimated irrespectively of the oak species were also found to differ among distances from the forest edge (Gehan's Wilcoxon statistic $=364.130, \mathrm{df}=4, p<0.001)$. Acorns were removed faster from experimental units located $50 \mathrm{~m}$ inwards the forest, while no differences were found between trays located $20 \mathrm{~m}$ inwards the forest and those located at the forest edge (Fig. 2b). Acorn removal rates in the clearing were lower than within the forest and the edge, although in this habitat trays located at -50 $\mathrm{m}$ had lower removal rates than trays located at -20 m (Fig. 2b).

Significant differences were found when acorn removal rates were compared among oak species at each distance from the forest edge (Tab. 1). Within the forests and in the clearing, Q. eduardii had higher removal rates than all the other oak species (Fig. 3). At the forest edge, on the other hand, acorns of Q. eduardii and Q. castanea were more intensely removed than those of the other oak species (Fig. 3). At all distances from the forest edge, white oaks ( $Q$. resinosa and $Q$. rugosa) had lower acorn removal rates than red oaks (Q. affinis, Q. castanea and Q. eduardii), but removal rates of $Q$. resinosa were always lower than those of Q. rugosa (Fig. 3). On the other hand, removal rates of all oak species differed among distances from the forest edge, except for Q. resinosa (Tab. 1). As mentioned above, only the acorns of $Q$. eduardii were fully removed in all experimental sites. However, removal rates of this oak species were higher $50 \mathrm{~m}$ inwards the forest and they sequentially decreased towards the clearing (Fig. 3). Removal rates of $Q$. affinis were also higher $50 \mathrm{~m}$ inwards the forest, but trays located $20 \mathrm{~m}$ inwards the forests and at the forest edge had higher removal rates than trays located in the clearing (Fig. 3). Acorns of Q. castanea and Q. rugosa had similar removal rates at both distances inwards the forest $(20 \mathrm{~m}$ and $50 \mathrm{~m})$ and at the forest edge (0 $\mathrm{m}$ ), and these values were always higher than those estimated at both distances ($20 \mathrm{~m}$ and $-50 \mathrm{~m}$ ) inwards the clearing (Fig. 3). 

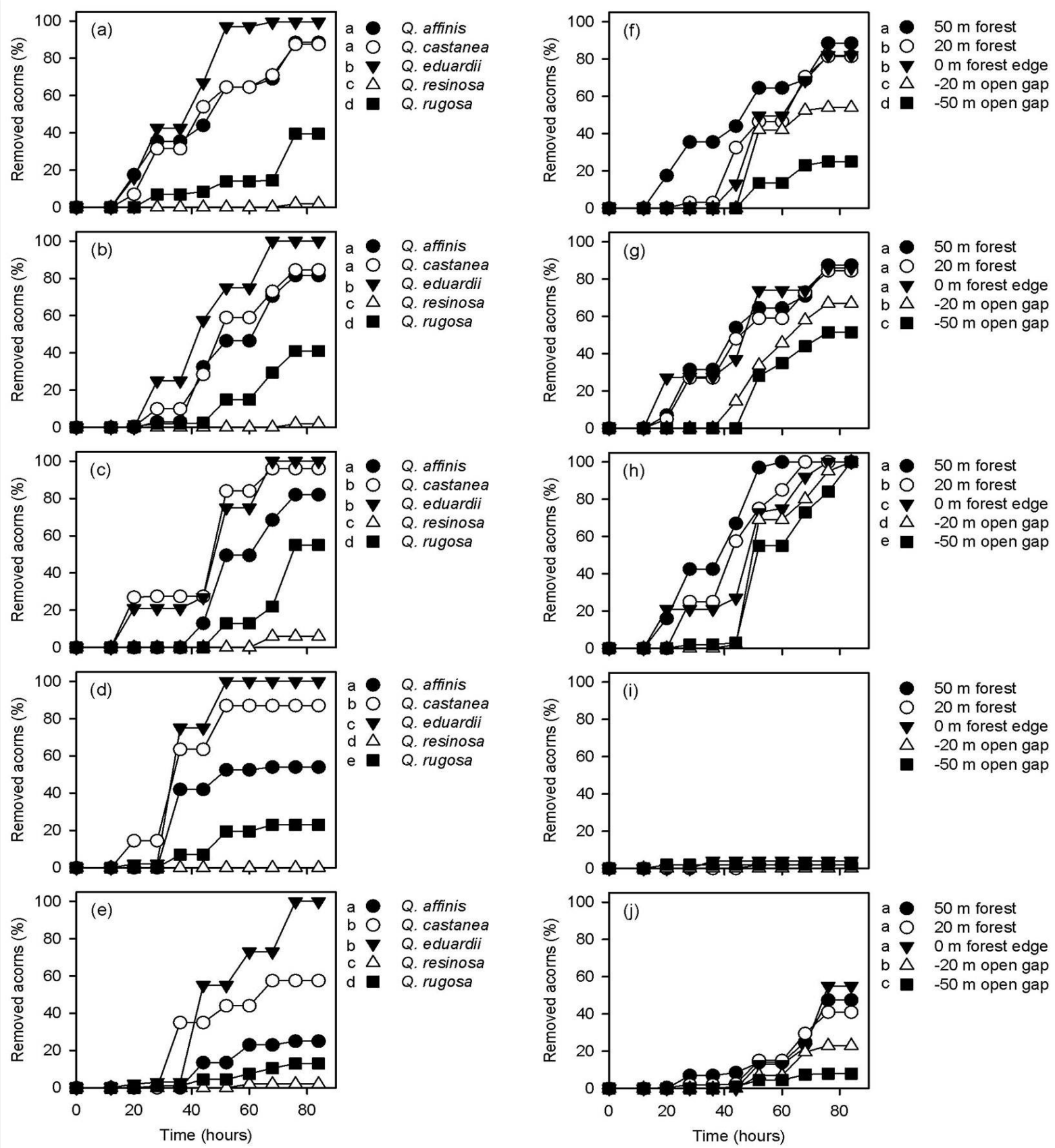

Fig. 3 - Acorn removal rates of the different oak species at different distances from the forest edge (a: $50 \mathrm{~m}$; b: $20 \mathrm{~m}$; c: $0 \mathrm{~m}$; d: -20 $\mathrm{m}$, e: $-50 \mathrm{~m}$ ) and at different distances from the forest edge for each oak species (f: Q. affinis; g: Q. castanea; h: Q. eduardii; i: Q. resinosa; j: Q. rugosa). In all cases, different letters on the side of symbols indicate significant differences $(p<0.05)$ between mean removal rates after Gehan's Wilcoxon test.

Tab. 2 - Frequency of occurrence of granivorous species (number of times they were captured with phototraps) visiting the acorn trays located within the forest $(20$ and $50 \mathrm{~m})$, at the forest edge $(0 \mathrm{~m})$ and in the clearing $(-50$ and $-20 \mathrm{~m})$. Symbols on the side of each number indicate the results of Monte Carlo randomization tests. (+): Visitation frequency higher than expected by chance (i.e., positive association between the species and a given distance to forest edge); (-): visitation frequency lower than expected by chance (negative association); (0): visitation frequency consistent with that expected by chance (neutral association pattern).

\begin{tabular}{|c|c|c|c|c|c|c|}
\hline \multirow[t]{2}{*}{ Family } & \multirow[t]{2}{*}{ Species } & \multicolumn{2}{|c|}{ Within the forest } & \multirow{2}{*}{\begin{tabular}{|c|}
$\begin{array}{c}\text { Forest } \\
\text { edge }\end{array}$ \\
$0 \mathrm{~m}$
\end{tabular}} & \multicolumn{2}{|c|}{ Clearing } \\
\hline & & $50 \mathrm{~m}$ & $20 \mathrm{~m}$ & & $-20 \mathrm{~m}$ & $-50 \mathrm{~m}$ \\
\hline Corvidae & Aphelocoma ultramarina (Bonaparte, 1825) & $347^{(+)}$ & $303^{(0)}$ & $309^{(0)}$ & $157^{(-)}$ & $124^{(-)}$ \\
\hline Picidae & Melanerpes formicivorus (Swainson, 1827) & $5^{(+)}$ & $0^{(-)}$ & $0^{(-)}$ & $0^{(-)}$ & $0^{(-)}$ \\
\hline Tayassuidae & Pecari tajacu (Linnaeus, 1758) & $7^{(+)}$ & $3^{(0)}$ & $0^{(-)}$ & $0^{(-)}$ & $0^{(-)}$ \\
\hline Cricetidae & Peromyscus sp. & $92^{(+)}$ & $56^{(0)}$ & $60^{(0)}$ & $8^{(-)}$ & $10^{(-)}$ \\
\hline Sciuridae & Sciurus oculatus (Peters, 1863) & $12^{(+)}$ & $11^{(+)}$ & $9^{(0)}$ & $0^{(-)}$ & $0^{(-)}$ \\
\hline Canidae & Urocyon cinereoargenteus (Schreber, 1775) & $8^{(+)}$ & $2^{(0)}$ & $3^{(0)}$ & $3^{(0)}$ & $1^{(0)}$ \\
\hline
\end{tabular}



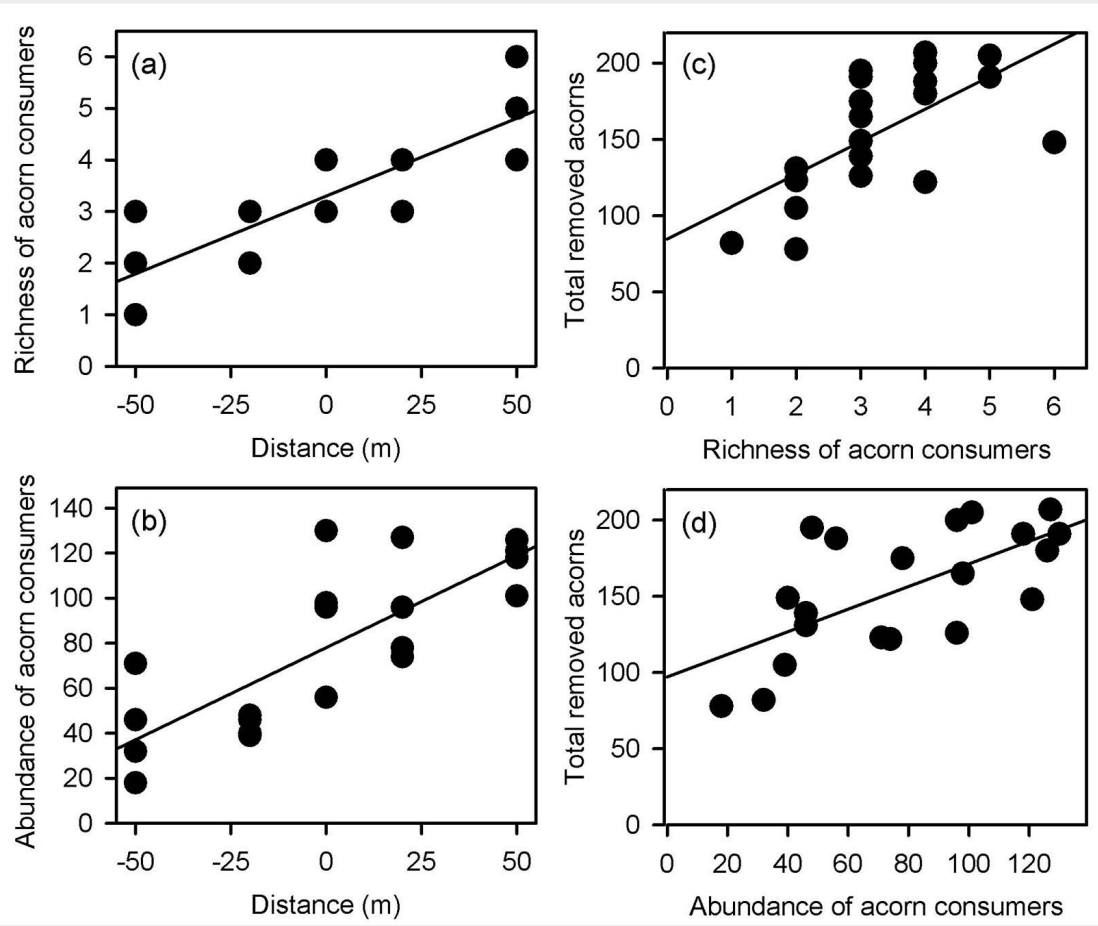

Fig. 4 - Relationships of richness (a) and total abundance of acorn consumers (b) with distance from the forest edge, and relationship between the total number of removed acorns and the richness (c) and abundance of granivores (d).

\section{Distribution patterns of acorn}

consumers

Six vertebrate species of consumers were recorded in the experimental trays (Fig. 1). Acorn consumers included Mexican jays (Aphelocoma ultramarina), acorn woodpeckers (Melanerpes formicivorus), collared

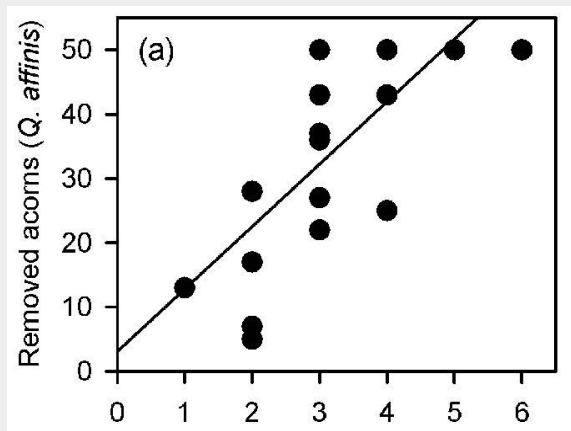

Richness of acorn consumers

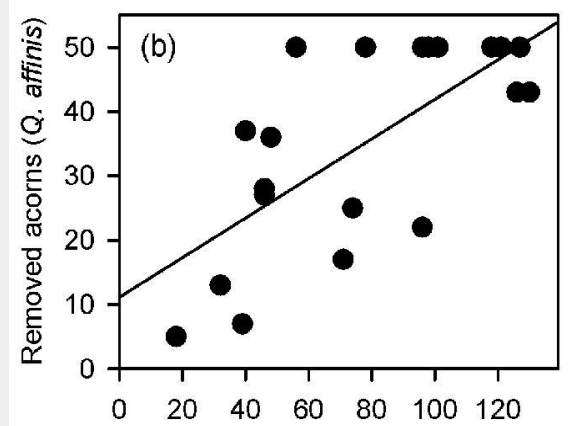

Abundance of acorn consumers peccaries (Pecari tajacu), Mexican field mice (Peromyscus sp.), Peter's squirrels (Sciurus oculatus) and gray foxes (Urocyon cinereoargenteus). Jays, woodpeckers and squirrels were only detected during daytime (from 06:00 to 18:00), while peccaries, mice and foxes were only recorded

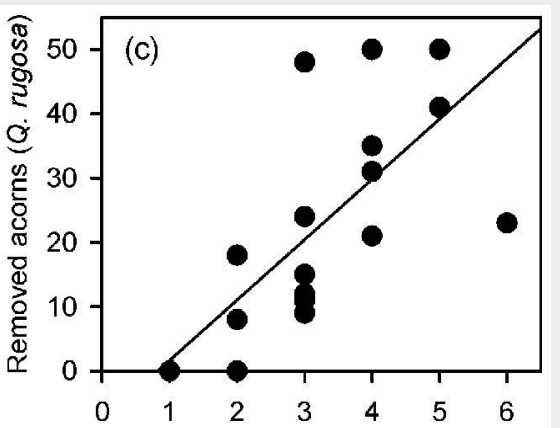

Richness of acorn consumers

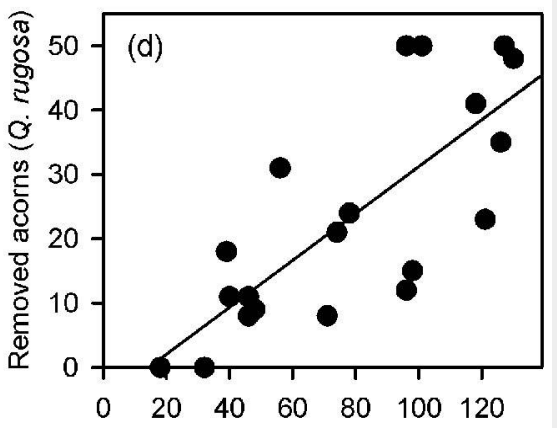

Abundance of acorn consumers
Fig. 5 - Relationships of the number of removed acorns of Quercus affinis (a, b) and Quercus rugosa (c, d) with the richness $(a, c)$ and total abundance (b, d) of granivores. during night (from 18:00 to 06:00). At all distances from the forest edge, the frequency of occurrence for jays and mice was much higher than that recorded for the other acorn consumers (Tab. 2).

Acorn consumers decreased their frequency from the forest interior towards the forest edge, and these values decreased even farther inwards the clearing (Tab. 2). The Monte Carlo randomization tests indicated that the visitation frequency of all these animals was higher than expected by chance in $50 \mathrm{~m}$ inwards the forest (Tab. 2). Experimental sites located 20 $\mathrm{m}$ inwards the forest were also visited by most acorn consumers, but only S. oculatus was positively associated with this habitat, while $M$. formicivorus was negatively associated (Tab. 2). No animal species was positively associated with the forest edge, while $M$. formicivorus and P. tajacu displayed negative associations with this habitat (Tab. 2). Visitation frequencies of most granivores were lower than expected by chance in the experimental sites located at $-20 \mathrm{~m}$ and $-50 \mathrm{~m}$ in the clearing (Tab. 2), indicating that most of them avoided this habitat. The only exception was $U$. cinereoargenteus, which displayed neutral associations at both distances inwards the clearing (Tab. 2).

\section{Relationships between acorn removal and the richness and abundance of consumers}

Both richness and total abundance of acorn consumers linearly increased from the maximum distance inwards the clearing towards the forest interior (richness: $\mathrm{F}_{[1,18]}=53.702, \mathrm{p}<0.001, \mathrm{r}^{2}=0.749$ - Fig. 4a; abundance: $F_{[1,18]}=30.851, p<0.001, r^{2}=$ 0.631 - Fig. 4b). Accordingly, the total number of removed acorns increased with richness and total abundance of granivores (richness: $F_{[1,18]}=12.563, p=0.002, r^{2}=0.411$ - Fig. 4C; abundance: $F_{[1,18]}=13.771, p=$ $0.001, r^{2}=0.434-$ Fig. $4 d$ ). However, the regression analyses conducted separately for each oak species did not fully support these overall removal pattern. Positive relationships between the number of removed acorns and richness and abundance of granivores were only found for Q. affinis (richness: $F_{[1,18]}=22.385, p<0.001, r^{2}=$ 0.554 - Fig. 5a; abundance: $F_{[1,18]}=16.952$, $\mathrm{p}<0.001, r^{2}=0.485-$ Fig. $\left.5 b\right)$ and $Q$. rugosa (richness: $F_{[1,18]}=14.551, p=0.001, r^{2}=$ 0.447 - Fig. 5c; abundance: $F_{[1,18]}=16.952, p$ $<0.001, r^{2}=0.485-$ Fig. $5 d$ ), while these relationships were not found for $Q$. castanea (richness: $F_{[1,18]}=0.243, p=0.628, r^{2}=0.013$; abundance: $F_{[1,18]}=0.414, p=0.528, r^{2}=$ 0.022 ) and $Q$. resinosa (richness: $F_{[1,18]}=$ 1.442, $p=0.245, r^{2}=0.074$; abundance: $F_{[1,18]}$ $\left.=0.003, p=0.961, r^{2}=0.001\right)$. We did not perform these analyses for Q. eduardii because its acorns were completely removed from all experimental units by the end of the experiment. On the other hand, when the individual effects of granivorous species were analyzed, a weak positive rela- 
Fig. 6 - Relationship between the total number of removed acorns and the abundance of Mexican jays (Aphelocoma ultramarina). $\mathrm{F}_{[1,18]}=$ 8.126, $p=0.011, R^{2}=0.311$.

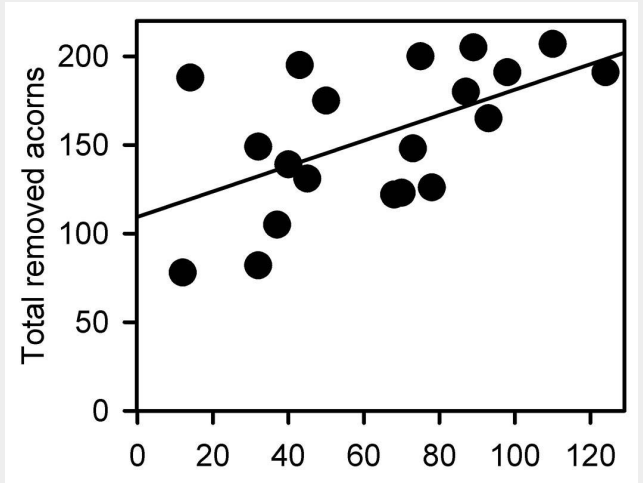

Abundance of Mexican jays tionship was found between the total number of removed acorns and the abundance of Mexican jays $\left(\mathrm{F}_{[1,18]}=8.126, \mathrm{p}=0.011, \mathrm{r}^{2}=\right.$ 0.311 - Fig. 6), but no relationships were found for the other granivores (data not shown).

\section{Discussion}

Our results suggest that granivorous vertebrates alter their activity patterns along the forest-edge-clearing gradient, which in turn causes changes in their richness and abundance across these habitats. The six species of acorn consumers recorded in this study exhibited a positive association with the forest habitat, while most of them were negatively associated with the manmade clearing. These results agree with the widely accepted hypothesis that impacts of human activities on forest landscapes reduces the diversity of wild animals (Kattan \& Alvarez-López 1996, Cordeiro \& Howe 2001, Wright 2003). Consistently with these distribution patterns of granivores, acorn removal rates gradually decreased from the forest interior towards the forest edge and, for most oak species, they abruptly decreased in the clearing. Previous studies have reported that seed removal rates in HMF decrease from the interior of forests towards human-impacted areas (Sork 1983, Webb \& Willson 1985, McCormick \& Meiners 2000, López-Barrera et al. 2005, Bustamante et al. 2012), but richness and abundance of seed consumers have been barely considered to explain seed removal patterns. In this study, acorn removal rates correlated with these two variables (richness and abundance of granivores) and their values decreased from the maximum distance inwards the forest (50 $\mathrm{m}$ ) towards the maximum distance in the man-made clearing $(-50 \mathrm{~m})$. To the best of our knowledge, this is the first study reporting the relationship between the reduction of seed removal chance in a manmade clearing and the decrease in richness and abundance of seed consumers.

Our results also indicate that different oak species have differential consumption patterns. Oak species with bigger acorns (Q. resinosa) showed extremely low removal rates (less than 10\%), even within the forest, which is the habitat that most granivores seems to prefer. This is somewhat counterintuitive because large animals which manipulate and consume these acorns (e.g., collared peccaries and grey foxes) were positively associated with the forest. Therefore, it could be hypothesized that the acorns of this oak species are not palatable for the fauna that currently inhabit this HMF. Alternatively, Q. resinosa may require highly specialized granivores that are no longer present in the study area. This may be the case of the wild turkey (Meleagris gallopavo), which is an important acorn consumer in most oak forests of North America (Steffen et al. 2002), but this bird species was extinguished in most temperate forest of Mexico because of intense poaching (Márquez-Olivas et al. 2005, Camacho-Escobar et al. 2011). Such scarce consumption of $Q$. resinosa acorns deserves more attention in future studies and their chemical composition should be determined to evaluate whether they contain unpalatable compounds for wild animals.

Acorn removal rates of all other oak species (Q. affinis, Q. castanea, Q. eduardii and $Q$. rugosa) decreased from the forest towards the man-made clearing, though removal patterns not always concurred with changes in richness and abundance of granivores. Removal rates of Q. affinis and Q. rugosa consistently decreased with the reduction in richness and abundance of granivores along the forest-edge-clearing gradient. This agrees with the general suggestion that human-induced disturbances can disrupt the ecological processes that take place in natural ecosystems (Solé \& Montoya 2001). These results suggest that the opening of man-made clearings can change the behaviour of granivores, as most these animals seemed to avoid the clearing even when food resources were available. Thus, the decreasing removal rates of $Q$. affinis and $Q$. rugosa from the forest to the clearing may be linked with a simplification of the community of consumers towards the clearing, thus reducing the probability that different animal species could perform the same ecological role. On the other hand, although acorn removal rates of Q. castanea decreased from the forest towards the clearing, they were neither related with changes in richness nor abundance of granivores. As compared with Q. affinis and Q. rugosa, this is likely due to a higher palatability of Q. castanea acorns for most granivores, as reflected by the higher removal rate of its acorns observed in most habitats.

The exception to these removal patterns was $Q$. eduardii, whose acorns were completely removed irrespectively of the habitat where they were placed. These elevated acorn removal rates, as compared with those of the other oak species, may be attributed to differential preferences of their consumers. Acorns of Q. eduardii are much smaller than those of the other oaks species included in this study, and this facilitates their manipulation by the small-bodied consumers, such as jays and mice. The marked preference of these granivores for this oak species could also be linked with an elevated palatability of these acorns (Smallwood et al. 2001).

Despite the specific removal patterns recorded for each oak, it is important to highlight that total acorn removal was positively related with the abundance of Mexican jays across the forest-edge-clearing gradient, and this was the only granivorous species that displayed such a relationship. This indicate that Mexican jays are important consumers (and scatterers) of acorns across all habitats of the forest-edge-clearing gradient. Nevertheless, it can be concluded that the elevated acorn removal within the forest is the result of a large number of interactions between these fruits and their consumers.

\section{Conclusions}

This study indicates that richness and abundance of granivorous vertebrates decrease along the forest-edge-clearing gradient of our study site. The total number of removed acorns (i.e., irrespective of the oak species) decreased with the decrease in richness and abundance of seed consumers. This relationship provide insights about how the opening of man-induced clearings can alter fundamental ecosystem processes in oak forests. However, it is worth to note that some of the oak species studied departed from this general pattern. Differences among oak species may be due to differential abilities of granivores to manipulate acorns of different size, which in turn may have important consequences on forest regeneration. Large granivores, such as foxes and peccaries, are not likely to contribute to forest regeneration as they directly consume the acorns (Kirkpatrick \& Pekins 2002). Conversely, small vertebrates, such as mice and squirrels, usually store large amounts of acorns in soil catches (Vander Wall 2010, Kellner et al. 2016), thus favouring seed dispersal and oak forest regeneration. Indeed, because most granivores avoid visiting forest clearings to reduce their predation risk, some 
scatter-hoarding rodents locate their acorn catches in these habitats to prevent pilferage of their food reserves (Muñoz \& Bonal 2011). As several acorn catches are latter forgotten, this promotes acorn germination in safe sites and allows forest regeneration in clearings (Vander Wall 2010, Kellner et al. 2016). Moreover, our results indicate that Mexican jays can also act as important acorn dispersers in HMF, as these birds may lose the acorns while flying (Steele \& Smallwood 2002). Our findings highlight the importance of animal-mediated secondary dispersion in the regeneration of oak forests, and the negative effect of large man-made clearings on the community of consumers, as most potential acorn dispersers seem to avoid these habitats.

\section{Acknowledgments}

We are grateful with the owners of the Wildlife Management Unit "La Laguna", Ana Mayra de la Garza and José Luis Carrera, for the logistic support provided during this study. We thank JP Rodas-Ortiz for his support during the collection of the acorns. We also thank the valuable comments of the three anonymous reviewers that contributed to improve the earlier versions of the manuscript. This study was supported by project SEP-CONACYT CB2013/221623 to EIB.

\section{References}

Bossema I (1979). Jays and oaks: An eco-ethological study of a symbiosis. Behaviour 70: 1-117. doi: 10.1163/156853979X00016

Bustamante RO, Badano El, Pickett STA (2012). Impacts of land use change on seed removal patterns of native and exotic species in a forest landscape. Community Ecology 13: 171-177. - doi: 10.1556/ComEc.13.2012.2.6

Cadenasso ML, Pickett STA (2000). Linking forest edge structure to edge function: mediation of herbivore damage. Journal of Ecology 88: 3144. - doi: 10.1046/j.1365-2745.2000.00423.x

Camacho-Escobar MA, Jiménez-Hidalgo E, Arroyo-Ledezma J, Sánchez-Bernal El, Pérez-Lara E (2011). Historia natural, domesticación y distribución del guajolote (Meleagris gallopavo) en México [Natural history, domestication and distribution of the turkey (Meleagris gallopavo) in Mexico]. Universidad y Ciencias 27: 351-360. [in Spanish with English summary]

Canale GR, Peres CA, Guidorizzi CE, FerreiraGatto CA, Kierulff MCM (2012). Pervasive defaunation of forest remnants in a tropical biodiversity hotspot. PLoS ONE 7 (8): e41671. - doi: 10.1371/journal.pone.0041671

Caro T, Sherman PW (2012). Vanishing behaviors. Conservation Letters 5: 159-166. - doi: 10.1111/j.17 55-263X.2012.00224.x

Cordeiro NJ, Howe HF (2001). Low recruitment of trees dispersed by animals in African forest fragments. Conservation Biology 15: 1733-1741. doi: 10.1046/j.1523-1739.2001.99579.x

De Blois S, Domon G, Bouchard A (2002). Landscape issues in plant ecology. Ecography 25: 244-256. - doi: 10.1034/j.1600-0587.2002.25021 2.x
Donoso DS, Grez AA, Simonetti JA (2003). Effects of forest fragmentation on the granivory of differently sized seeds. Biological Conservation 115: 63-70. - doi: 10.1016/Sooo6-3207(03)00 094-6

Díaz I, Papic C, Armesto JJ (1999). An assessment of post-dispersal seed predation in temperate rain forest fragments in Chiloe Island, Chile. Oikos 87: 228-238. - doi: 10.2307/3546738

FAO (2010). Global forest resources assessment. Food and Agriculture Organization of the United Nations, Rome, Italy, pp. 340.

Fortin MJ, Jacquez GM (2000). Randomization tests and spatially auto-correlated data. Bulletin of the Ecological Society of America 81: 201-205. [online] URL: http://www.jstor.org/sta ble/20168439

García E (2004). Modificaciones al sistema de clasificacion climatica de Koppen [Modifications to the Köppen climate classification system] ( $5^{\text {th }}$ edn). Universidad Nacional Autóma de México, México City, pp. 91. [in Spanish] González-Salvatierra C, Badano El, Flores J, Rodas JP (2013). Germination, infestation, and viability in acorns of Quercus polymorpha (Schltdl. \& (ham.) after 1-year storage. Revista Chapingo Serie Ciencias Forestales y del Ambiente 19: 351-362. - doi: 10.5154/r.rchscfa.2012.07.044 Gribko LS, Jones WE (1995). Test of the float method of assessing northern red oak acorn condition. Tree Planters' Notes 46: 143-147. [online] URL: http://www.cabdirect.org/cabdirec t/abstract/19970608981

Hood GM (2011). PopTools ver. 3.2. Web site. [online] URL: http://www.poptools.org

Kaplan EL, Meier P (1958). Nonparametric estimation from incomplete observations. Journal of the American Statistical Association 53: 457481. - doi: 10.1080/01621459.1958.10501452

Kattan G, Alvarez-López H (1996). Preservation and management of biodiversity in fragmented landscapes in the Colombian Andes. In: "Forest Patches in Tropical Landscapes" (Schelhas J, Greenberg $\mathrm{R}$ eds). Island Press, Washington, DC, USA, pp. 3-18. [online] URL: http://books. google.com/books?id=Ugq8BwAAQBAJ

Kellner KF, Lichti NI, Swihart RK (2016). Midstory removal reduces effectiveness of oak (Quercus) acorn dispersal by small mammals in the Central Hardwood Forest region. Forest Ecology and Management 375: 182-190. - doi: 10.1016/j. foreco.2016.05.042

Kirkpatrick RL, Pekins PJ (2002). Nutritional value of acorns for wildlife. In: "Oak Forest Ecosystems: Ecology and Management for Wildlife" (McShea WJ, Healy WM eds). Johns Hopkins University Press, Baltimore, USA, pp. 173181.

Kleinbaum DG, Klein M (2012). Survival analysis ( $3^{\text {rd }}$ edn). Springer, New York, USA, pp. 700. [online] URL: http://link.springer.com/book/10. 1007/978-1-4419-6646-9

Kollmann J, Buschor M (2003). Edges effects on seed predation by rodents in deciduous forests of northern Switzerland. Plant Ecology 164: 249-261. - doi: 10.1023/A:1021225728493 López-Barrera F, Manson RH (2006). Ecology of acorn dispersal by small mammals in montane forests of Chiapas, Mexico. In: "Ecology and Conservation of Neotropical Montane Oak Forests" (Kappelle M ed). Springer, Berlin, Ger- many, pp. 165-176. - doi: 10.1007/3-540-28909713

López-Barrera F, Newton A, Manson R (2005). Edge effects in a tropical montane forest mosaic: experimental tests of post-dispersal acorn removal. Ecological Research 20: 31-40. - doi: 10.1007/s11284-004-0016-7

Martínez M (1981). Los encinos de México [Oaks of Mexico] ( $2^{\text {nd }}$ edn). Comisión Forestal del Estado de Michoacán, Morelia, México, pp. 358. [in Spanish]

McCormick JT, Meiners SJ (2000). Season and distance from forest-old field edge affect seed predation by white-footed mice. Northeastern Naturalist 7: 7-16. - doi: 10.1656/1092-6194(2000) 007[0007:SADFFO]2.0.CO;2

Márquez-Olivas M, García-Moya E, GonzálezRebeles C (2005). Composición de la dieta del guajolote silvestre (Meleagris gallopavo mexicana, Gould, 1856) reintroducido en Sierra Fría, Aguascalientes, México [Diet composition of reintroduced wild turkey (Meleagris gallopavo mexicana, Gould, 1856) in Sierra Fria, Aguascalientes, Mexico]. Veterinaria México 36: 395409. [in Spanish with English summary]

Muñoz A, Bonal R (2011) Linking seed dispersal to cache protection strategies. Journal of Ecology 99: 1016-1025. - doi: 10.1111/j.1365-2745.2011. 01818.x

Nixon KC (1993). The genus Quercus in México. In: "Biological Diversity of Mexico: Origins and Distribution" (Ramamoorthy TP, Bye R, Lot A, Fa J eds). Oxford University Press, New York, USA, pp. 447-548.

Paul J, Crutzen PJ (2006). The Anthropocene. In: "Earth System Science in the Anthropocene" (Ehlers E, Krafft T eds). Springer, Berlin, Germany, pp. 13-18. - doi: 10.1007/3-540-26590-2 3 R Development Core Team (2016). R: a language and environment for statistical computing. $R$ Statistical Foundation, Vienna Austria. [online] URL: http://www.r-project.org

Ramos-Palacios CR, Badano EI (2014). The relevance of burial to evade acorn predation in an oak forest affected by habitat loss and land use changes. Botanical Sciences 92: 299-308. - doi: 10.17129/botsci.101

Ramos-Palacios C, Badano E, Flores J, FloresCano J, Flores-Flores J (2014). Distribution patterns of acorns after primary dispersion in a fragmented oak forest and their consequences on predators and dispersers. European Journal of Forest Research 133: 391-404. - doi: 10.1007/ s10342-013-0771-5

Redford KH (1992). The empty forest. BioScience 42: 412-422. - doi: 10.2307/1311860

Rey-Benayas JM, Martínez-Baroja L, Pérez-Camacho L, Villar-Salvador P, Holl KD (2015). Predation and aridity slow down the spread of 21year-old planted woodland islets in restored Mediterranean farmland. New Forests 46: 841853. - doi: 10.1007/s11056-015-9490-8

Rizkalla CE, Swihart RK (2007). Explaining movement decisions of forest rodents in fragmented landscapes. Biological Conservation 140: 339348. - doi: 10.1016/j.biocon.2007.08.019

Rosete-Vergés FA, Pérez-Damián JL, VillalobosDelgado M, Navarro-Salas EN, Salinas-Chávez E, Remond-Noa R (2014). El avance de la deforestación en México 1976-2007 [The progress of the deforestation in Mexico 1976-2007]. Made- 
ra y Bosques 20: 21-35. [in Spanish] - doi: 10.218 29/myb.2014.201173

Schleimann SA, Bockheim JG (2011). Methods for studying treefall gaps: a review. Forest Ecology and Management 261: 1143-1151. - doi: 10.1016/j. foreco.2011.01.011

Slade NA (1999). Randomization tests using standard statistical software. Bulletin of the Ecological Society of America 80: 179-180. - doi: 10.1890/0012-9623(1999)080[0179:E]2.0.CO;2

Smallwood PD, Steele MA, Faeth SH (2001). The ultimate basis of the caching preferences of rodents and the oak-dispersal syndrome: tannins, insects, and seed germination. American Zoologist 41: 840-851. - doi: 10.1668/0003-1569 (2001)041[0840:TUBOTC]2.0.CO;2

Solé RV, Montoya M (2001). Complexity and fragility in ecological networks. Proceedings of the Royal Society of London B 268: 2039-2045. doi: 10.1098/rspb.2001.1767

Sork VL (1983). Distribution of pignut hickory (Carya glabra) along a forest to edge transect, and factors affecting seedling recruitment. Bulletin of the Torrey Botanical Club 110: 494-506. - doi: $10.2307 / 2996284$

Steele MA, Smallwood PD (2002). Acorn dispersal by birds and mammals. In: "Oak Forest Ecosystems: Ecology and Management for Wildlife" (McShea WJ, Healy WM eds). Johns Hopkins University Press, Baltimore, USA, pp. 182-195.

Steele MA, Smallwood PD, Spunar A, Nelsen E (2001). The proximate basis of the oak dispersal syndrome: Detection of seed dormancy by rodents. American Zoologist 41: 852-864. - doi: 10.1668/0003-

1569(2001)041[0852:TPBOTO]2.0.CO;2

Steffen DE, Lafon NW, Norman GW (2002). Turkey, acorns and oaks. In: "Oak Forest Ecosystems: Ecology and Management for Wildlife" (McShea WJ, Healy WM eds). Johns Hopkins University Press, Baltimore, USA, pp. 241-255.

Swihart RK, Atwood TC, Goheen JR, Scheiman DM, Munroe KE, Gehring TM (2003). Predicting patch occupancy of North American mammals: Is patchiness in the eye of the beholder? Journal of Biogeography 30: 1259-1279. - doi: 10.104 6/j.1365-2699.2003.00925.x
Vander Wall SB (2010). How plants manipulate the scatter-hoarding behaviour of seed-dispersing animals. Philosophical Transactions of the Royal Society of London B 365: 989-997. - doi: 10.1098/rstb.2009.0205

Webb SL, Willson MF (1985). Spatial heterogeneity in post-dispersal predation on Prunus and Uvularia seeds. Oecologia 67: 150-153. - doi: 10.1007/BFo0378468

Wolff JO (1996). Population fluctuations of masteating rodents are correlated with production of acorns. Journal of Mammalogy 77: 850-856. doi: $10.2307 / 1382690$

Wright SJ (2003). The myriad effects of hunting for vertebrates and plants in tropical forests. Perspectives in Plant Ecology, Evolution and Systematics 6: 73-86. - doi: 10.1078/1433-8319-0 0043

Zavala-Chávez F (2001). Introducción a la ecología de la regeneración natural de encinos [Introduction to the ecology of the natural regeneration of oaks]. Universidad Autónoma Chapingo, Texcoco, México, pp. 94. [in Spanish] 